\title{
An action research report on the rising democracy discourse in 2000's Turkey: Does Eros contour the demos? ${ }^{\text {th }}$
}

\author{
Dilek Cindoglu $^{\mathrm{a}, *}$, Adnan Boynukara ${ }^{\mathrm{b}}$, Selin Akyuz ${ }^{\mathrm{a}}$, Edip A. Bekaroğlu ${ }^{\mathrm{a}}$ \\ ${ }^{a}$ Bilkent University Faculty of Economics, Administrative and Social Sciences, Department of Political Science, Turkey \\ ${ }^{\mathrm{b}}$ Ankara Turkey
}

Available online 24 October 2007

\section{Synopsis}

This article conceptualizes gender equity and sexual liberty issues that most of the literature on democracy and democratization in Turkey fails to address. The major focus of the article is on the convergent and divergent positions of the rising democratization discourse in contemporary Turkey. When the democratization discourses of different political groups are analyzed, we see that the convergent points consist of legal and constitutional changes that aim at political and economic liberalization, while the divergent points include liberalization in the private sphere and engaging in gender equity and sexual liberty issues. Therefore, we argue that it is crucial to analyze gender equity and sexual liberty issues with more dynamic concepts such as globalization and the EU accession process of Turkey rather than the essentialist ones like Islam.

(C) 2007 Elsevier Ltd. All rights reserved.

"Generalizations that lead to essentialist conclusions necessarily hide the diversity which exists in both the east and the west." (Elsadda, 2004, p.45)

\section{Introduction}

In order to become a candidate country to join the European Union (EU), since 1999, the governments in Turkey have been obliged to further liberalize and democratize the political regime in conformity with the EU acquis (Heper, 2005, p.37). Özbudun (2000) states that the main problems of democratic consolidation in Turkey are firstly the de-institutionalization of the political party system as a consequence of growing

\footnotetext{
Th This research has been partially supported by a generous grant from TUBITAK (The Scientific and Technological Research Council of Turkey).

* Corresponding author.
}

electoral volatility, fragmentation and polarization; secondly constitutional problems such as lack of popular debate on tutelary powers and reserved domains granted to military, problems concerning fundamental rights and liberties; and thirdly the challenges which stem from political Islam and Kurdish nationalism. Since the preconditions that must be fulfilled for the EU membership require overcoming the problems especially in the second and the third categories, the EU process and deepening democracy in Turkey are considered to be the two interconnected phenomenon. Indeed, the Helsinki Summit (December 1999), which ascribed Turkey with candidacy status, asked Turkey to comply with membership requirements as set by the Copenhagen European Council (June 1993), which include ensuring the stability of institutions, guaranteeing complete freedom of expression, human rights, respect and protection for minorities and an efficient market economy (Cizre, 2003, p.223). Not only the governments have displayed strong political will to restructure the Turkish legal 
system and politics in accordance with the Copenhagen criteria, but other actors such as the opposition parties (representing Kurdish agenda and political Islam), civil society organizations (women's organizations, gay and lesbian organizations, human rights associations and the Alawite $^{1}$ ), business and workers' organizations (right wing and left wing) and the media, have increasingly adopted a political discourse that supports the political and economic reforms.

This article is the result of a research project on the rising discourse on democracy in Turkey, and has been sponsored by a generous grant from TUBITAK (Scientific and Technological Research Council of Turkey) in 2005 and 2006. The goal of this research project is an in-depth analysis of the debate on democracy during the EU accession process of Turkey by identifying the bottlenecks and common denominators among the political actors in action research format. We claim that the absence of gender and sexuality issues in the democracy discourse in Turkey at the beginning of the 21 st century is the principle element of how the political elite imagine democracy and this fact is the most critical bottleneck of democracy in Turkey. Although gender is an important component of the democracy discourse; most of the literature on democracy and democratization in Turkey fails to evaluate gender issues, which this article aims to complement.

The relationship between gender and politics has been studied from many angles such as women's political participation, labor force participation, the movement for 'head cover' (hijab), and domestic violence, etc. Yet the way the democratization literature covers gender equity and sexual liberty issues has not been studied in depth. Gender politics needs to be understood in its own context. Moghadam provides an analytical framework by emphasizing the relationship between the rise of identity politics and the conservative values on gender and sexuality in the non-western world in general, and in Islamic societies in particular (Moghadam, 1994). To understand gender politics in the context of Turkey, we must date back its problem to the establishment of the Turkish Republic in 1923 under the leadership of Kemal Atatürk, and to the political and institutional reforms that gave women the right to participate in municipal (1930) and national elections in 1934 (Tekeli, 1998, p.341). These political rights to elect and to be elected made women politically equal to men, yet the traditional role of women has always been glorified, and women continued to be defined as the corner stones of the society, and they represented the purity of the newly born Turkish nation. As the mothers of the nation, they not only give birth to babies but also to the future of a nation. As Durakbașa argues 'Kemalism (...) did not alter the patriarchal norms of morality, and in fact maintained the basic cultural conservatism about male/female relations, despite its radicalism in opening a space for women in the public domain' (Durakbaşa, 1998, p.140). This paradox of Turkish nationalism gave rise to the current bottlenecks of Turkish democratization, but to be able to deal with them, one needs to understand the dynamics and motivations of the rising democracy discourse in Turkey.

Turkey's accession process to the EU has enjoyed a high rate of support from different segments of the Turkish society in the past decade. This support was the result of the hopes, motivations and expectations that different segments of the society had from the EU. The hopes and expectations of the economically disadvantaged groups were that their living standards would be improved; the unemployed hoped that there would be more job opportunities than the present; the workers believed that their conditions of work would be improved; the underrepresented groups (e.g. women, Kurds, Islamists, religious minorities, gays) dreamed of the social and political liberties that would come along with the EU accession process; the business circles desired a stable political and economic life that was crucial for their businesses to prosper; and the state elites of the Kemalists considered the EU accession as a natural component of their ultimate goal, namely catching up with contemporary civilization and modernization of the West. As a response to all these hopes and expectations, the political elites, from right to left wing, emphasized ensuring full accession to the EU as their first and foremost goal in their policy agendas. Not surprisingly, these high rates of support for the EU accession in the population went along with a rising democracy discourse since 'deepening democracy' is the major requirement for joining the EU as outlined by the Copenhagen Criteria.

The present article, will address the bottlenecks of the rising democracy discourse in Turkey in the context discussed above, and its relationship with the gender equity agenda. The questions are: What have been the parameters of the positive attitude in Turkey toward Turkey's accession to EU, particularly with relation to democratization? When they talk about democratization, what are different groups actually asking for? Which values, if any, associated with democracy, are favored over the others? Do different groups promote different kinds of democratic values?

Our research questions were formed around these concerns with reference to the convergent and divergent points that each political elite group claimed on the matter of democratization and EU process. Considering 
the widespread consensus in the public opinion on adopting the Copenhagen criteria, we expected to find that all political and social groups in Turkey would support the legal and constitutional changes that aimed at political and economic liberalization. However, considering also the political culture approach that is to be detailed in the Literature review of this article, we hypothesized that the point of resistance to deepening democratization in Turkey would consist of the issues that were related to the general cultural values of the Turkish society. In the democracy discourse of the different segments of the society, the convergent points would consist of legal and constitutional changes that aimed at political and economic liberalization, while divergent points would include the issues related to liberalization in the private sphere engaging gender and sexual liberty issues. In other words there would not be agreed definitions of democracy and democratic values in Turkey, and therefore, the democratic values would be variable from one political elite group to another; and the discourse on democracy and democratic values would vary with time, space, and conjuncture.

\section{Literature review}

Exploration and comprehension of the democratic values among the political elite of contemporary Turkish politics is at the heart of this research. Culture has been perceived a very critical component of any democracy since Max Weber $^{2}$ : the patterns of culture have been associated with the emergence and stability of democracy. In the modernization theory, the economic development and cultural development are two parallel phenomena, a mix of which, in turn, brings about democracy. There are many scholars who argue that the stability of a democracy needs a particular political culture that includes a commitment to democratic values or rules at least among the political elites, on participation, toleration, consensus, and the like (e.g. Dahl, Diamond, Eckstein, O'Donnell). However, there are also others who argue that democratization is the consequence of a particular political culture that is thought to be an outcome of a certain religion, economic development, industrialization, or social conflicts and wars. Prominent authors of the political culture approach, Gabriel Almond and Sidney Verba argue in Civic Culture: Political Attitudes \& Democracy in Five Nations (1963) that the prevalence of certain values and beliefs over others is necessary for the emergence of a stable and effective democracy. They identify three different political cultures: parochial, subject, and participant, prioritizing 'civic culture' as the most ideal political culture for democracy. The ideal civic culture of democracy requires not only participant but also other traditional or parochial attitudes. In other words, the citizen of democracy is expected be 'active, yet passive; involved, yet not too involved; influential, yet differential' (Almond \& Verba, 1963, p.479). Another wellknown study on the relationship between political culture, values and democracy is Robert D. Putnam's Making Democracy Work (1993) where he compares the Northern and Southern Italy in terms of socioeconomic modernization, civic involvement, and democratic performance. His findings suggest that, rather than the economic development, it is the distinct history/ culture of civic involvement, which consists of active participation in public affairs, the development of ideas of political equality, solidarity, trust, tolerance, and the formation of voluntary association that accounts for democratic performance. Perhaps, the most well-known hypothesis that establishes a direct relationship between democratization and culture is Huntington's 'Clash of Civilizations' (1993). He argues that culture, which he uses interchangeably with religion, explains why in some parts of the world especially in the Muslim world democracy is missing. He argues that the political values that gave birth to democracy in western civilizations lacks in Middle Eastern societies, which are dominated by Islam. These values are (1) separation of religious and secular authority, (2) rule of law, (3) social pluralism, (4) parliamentary institutions of representative government, and finally (5) protection of individual rights and civil liberties as being the buffer between citizens and the power of the state. Pippa Norris and Ronald Inglehart (2002) tested Huntington's thesis empirically with comparative research on the beliefs and values of Islamic and non-Islamic societies in seventy-five countries and confirmed it partially. According to this research, culture does matter, and religions do have important effects on contemporary social and political values. However, there are striking similarities in the political values held in different societies. According to Norris and Inglehart (2002), the real cultural gulf separating Islamic societies from their Western counterparts involves the values concerning gender equity and sexual liberalization far more than political democratic values such as participation, accountability, and the like. Norris and Inglehart, however, are more optimistic than Huntington and argue that economic development and modernization will cause changes in these values in the Muslim world in time.

One recent research project on conservatism in contemporary Turkey, namely 'Conservatism, Family, Religion and the West in Turkey' (Yilmaz, unpublished 
2006), suggests that the source of conservatism in Turkey is the family rather than the state. While previously state-centered politics were thought to be the major source of social and political conservatism in Turkey, Yilmaz's study refocuses the attention to the private sphere. It is surprising that alongside the increase in the process of democratization that accompanies the EU accession process, the level of conservatism among Turkish people is rising significantly. Another study, 'Sexual Regime Axis: Warm Family Environment', puts emphasis on the conservative values in the family (Bora \& Üstun, 2005). In this study, the norms and patterns about gender relationships are explored. The authors analyze how women perceive and interpret the repression and violence that they experience as they build/ form themselves as subjects in this restricted environment, and argue that such norms and patterns are conservative and anti-democratic in nature.

While the democratization literature is addressing its own failure in dealing with the complexities of democracy by bringing cultural arguments into the analysis, the blind spot of this literature is the absence of gender issues. This leads most students of 'democratization' to claim that some societies lack democratic values as a consequence of their cultures. Hence, the lack or shortcomings of democracy is put into to the equation 'culture = Islam'. We argue that the main bottlenecks of democracy are related to the lack of the notion of gender equity and not to the religious orientation and that it is that lack which counts for conservatism in any society. We agree with the work done by Elsadda (2004) which challenges the culturalist/essentialist perspective and highlights the simplicity of the 'sexual clash of civilization theory'. The author stresses that the approaches which explain gender issues with respect to culture/religion, oversimplify the diversity that exists in the Eastern and Western societies. She argues that issues such as abortion or low rate of women's participation into politics are not particular to Islamic societies. In parallel with this argument, the present article will elaborate this gender blind spot in the case of Turkey.

Historically speaking, Turkey as a secular, democratic country with a huge Muslim population, offers a fertile ground to examine gender and democracy issues. Interestingly, after the establishment of the Republic, when women attempted to establish the first political party (Women's Public Party, 1923), this project was not permitted by the political elites (Tekeli, 1998, p.341). Instead of a political party, Nezihe Muhittin and her friends did manage to establish the Turkish Women's Association and they had significant impact on the rising awareness about gender equity in Turkey, until their closure in 1935 (Kırkpinar, 2001, p.197). Although this Association had great impact on the progress of the role of women in the society in general and in politics in particular, they could not break the traditional vein. It was clear that the internalized traditional role of womanhood could not be erased easily. Rights given to increase the social and legal status of women defined women within certain boundaries. The women internalized the Kemalist nationalist ideology and the steps taken towards the emancipation of Turkish women created the 'modern but modest' women of the Republic (Kadığlu, 1996). Kandiyoti (1987) stresses that the Kemalist modernization project created 'emancipated but not liberated' women by desexualizing her body in the public.

During the multi party politics, after 1950, women's associations and organizations were oriented towards philanthropic goals, and they did not have much political objective (Çakır, 1996, p.751). In the 1970s, however, women's associations were established by women on the left, addressing general political issues with little or no reference to gender equity (Çakır, 1996). The military intervention of September 12, 1980 affected the whole of the political life of Turkey, including the closure of the political parties, groups, associations etc. Oddly enough, feminist activism corresponds to this period, although the level of representation of women in politics did not increase much (Eşim \& Cindoğlu, 1999). In other words, the mainstreaming of feminist activism did not occur in Turkey in the last two decades, therefore the percentage of local or national women representatives in the political arena did not increase and women's issues were not brought to the daily political agendas (Arat, 1998).

Modern democratic theory and classical debates question the inclusiveness of democratic systems (Phillips, 1991). Classical debates are not able to embrace the feminist criticism of democratic theory, which stress that there is (1) overemphasis on the democracy in the workplace, (2) ignorance of differences between men's and women's lives and embracing abstract individualism, and (3) overemphasis on public participation overlooking at the private sphere, namely women. Academic debates about women's political participation in Turkey refer to these issues as well. When women in public life are examined without making reference to the private sphere, this not only lacks the complexity of the phenomenon, but also lacks the cultural and social dimensions. Indeed, in the 'democratization' literature, there is an increasing emphasis on the significance of the private sphere for a well functioning democratic society. As it has been mentioned earlier, in the 'True Clash of Civilizations', Norris and Inglehart (2003) point out that Huntington was only half right; that 
is, the cultural fault line that divides the West and the Islamic world is not about democratic values regarding public life, but the expectations from private life, i.e. sexuality and gender equity. 'Huntington is mistaken in assuming that the core clash between the West and Islam is over political values. The real fault line between the West and Islam, which Huntington's theory completely overlooks, concerns gender equity and sexual liberalization. In other words, the values separating these cultures have much more to do with Eros, than demos.' (Norris \& Inglehart, 2003, p. 65).

\section{Data collection and methodology}

Norris and Inglehart's results have inspired this research, where we assert that in order to understand the desire of the Turkish people for further democratization, one must ask what the nature of democracy that they have in mind is. In other words, to what extent this desire for further democratization stands for a change in non-western cultures with respect to gender equity and respect for homosexual rights? Are Turkish people ready to tolerate not only those underrepresented 'sexual others' but also the 'political others' - those different from the mainstream political identity, namely Turkish versus other ethnicities, secular Kemalists vs. Islamists, Sunni Muslims vs. the Alawite?

The data comes from in-depth interviews and three workshops conducted towards the consensus building process on the bottlenecks of Turkish democracy. These workshops were the most distinctive features of our research project, where we not only collected our data through interviews but also shared that data in the interim report at the workshops with the participants, where they had an opportunity to revisit their position on democracy and democratic values.

Action research methodology has a long and diverse history including different types and typologies of action research endorsing different epistemologies and ontology. As has been discussed very extensively in Cassell and Johnson's work (2006), this methodology mostly emerged from organization studies, yet has been recently employed particularly by feminist studies due to its endorsement to the 'many ways of knowing' and empowering and informing the participants in the process of research (Reason, 2006, p.193). Our research also prioritized the empowerment and information sharing aspects of action research in the process by conducting group discussions in three different cities and sharing the preliminary findings with the participants.

The sampling strategy was to interview those who are in favor of the EU accession and who are considered as representative agents of certain categories, such as Islamists, leftists, liberals, conservatives, Kurds, the Alawite, feminists, gays and lesbians, representatives of employers and employees. These interviews were conducted in Diyarbakır as well as in Ankara and Istanbul. The groups we have included in this research can be categorized as follows: Members of the Parliament from different political parties; representatives of employer associations (TOBB - The union of Chambers and Commodity Exchanges of Turkey; TUSIAD Turkish Industrialists and Businessmen's Association; MUSIAD - Muslim Business Men's Association); representatives of labor unions (DISK - Confederation of Revolutionary Workers' Unions, TURKIS - Confederation of Workers' Unions of Turkey, HAKIS Confederation of Rule of the Righteous Workers' Unions); representatives of civil society associations (Alawite groups, Kurdish groups, Islamist groups, women's associations, gays and lesbians' associations, human rights associations). The sampling strategy emerged from extensive media coverage analyses where we first evaluated the statements of the aforementioned groups in print media. In doing so, we were surprised with the similarities in the attitudes of these groups for democracy and further democratization, and were encouraged to continue our research.

First, in-depth and open-ended interviews with a total of forty-three people were conducted in Ankara, Istanbul, and Diyarbakır between August and November 2005. In order to be able to reach comprehensive data, we were careful to include diverse and different persons in the sample from groups who are pro-EU accession process. In order to address the diversity issues, two Turkish intellectuals who are not in favor of Turkey's EU membership process, but openly emphasize democracy and democratic values in their writings are included.

Since our goal was to identify and elaborate our respondents' values on democracy, we chose to employ the in-depth interview technique. In these interviews, the questions previously prepared were asked to each respondent. With our open ended questions, we aimed at revealing (1) how the respondent evaluated the EU accession process personally and for the group he/she represented, (2) in which areas, the respondent thought, the EU process would bring about democratic changes, (3) to what extent the respondent wished to see the other or opposite groups benefit from these changes, and finally (4) with these possible democratic changes, what the respondent thought about the increasing representation of ethnic and religious minorities, women's participation in politics, women's rights, representation of different sexual identities, human rights, and intra-party democracy. When 
needed, some additional questions were asked to some of the respondents in order to understand their particular situations. During each interview, notes were taken and all the interviews were recorded. Research assistants were responsible from transcription and thematic coding of the forty-three interviews. The emerging themes were coded by 'tree system coding' using Microsoft word program. The emergent themes were analyzed and the interim report was prepared through these codings.

Sharing the interim report with some of our respondents in three workshops that we held in Ankara (04 March 2006), Diyarbakır (18 March 2006), and Istanbul (25 March 2006) constituted the second stage of the research. In doing so, we aimed at not only improving our data, but also to making some contribution to the consensus building process by providing a secure space for discussing the possible bottlenecks of the process of further democratization. In these workshops, we shared our findings-the bottlenecks and common denominators-with our respondents, gave them some headlines from our interviews, and made them re-think and re-consider their positions. At the end of each workshop, we were satisfied to witness how people from very different backgrounds, with different ideologies and political positions could reach agreement on some topics. They agreed on some matters, and agreed to disagree on some others, which is necessary for a peaceful democratic process. These workshops are one of the most distinctive features of our research project. After having feedbacks on our interim report, and strengthening the scope of our observations, we wrote the final version of our research report.

\section{Results}

From the start of this research project, we assumed that there were no agreed definitions of democracy and democratic values internalized by the political elite, who favored EU accession, in Turkey. Therefore, the democratic values would vary from one group to another. This hypothesis was supported in the research, suggesting that each political group hopes that its priorities will be satisfied with the freedoms that are to be established during the EU accession. Secondly, it was hypothesized that the discourse on democracy and democratic values would be variable with time, space, and conjuncture. This was also supported by our research: while all the respondents agreed on the importance of individual rights, when it came to gay rights, women's rights or the headscarf issue, most of them suggested that it was somewhat early to extend individual rights to such claims and groups.
With this project we were able to identify the differences and common denominators in our respondents' views on democratic values. The most important finding of our research is that while all of the common denominators among the respondents were about arrangements of the public sphere, the differences came to surface when we asked about private sphere, gender roles, and particularly about sexuality, and rights and liberties regarding gays and lesbians. Our respondents agreed on the necessity for a fairer representation of ethnic and religious identities in the public sphere in one way or another. Although welcoming the democratic opportunities that spring from the EU accession process, they were well aware of the fact that such opportunities did not stem from internal dynamics, but rather from the demands coming from the EU. Lack of internalization by the society as a whole and especially by the bureaucratic elite of the legal liberalization was identified by almost all the respondents.

For further democratization, the respondents emphasized the significance of (1) individual rights and freedom in communicating their ideas and in getting organized by legal means, (2) the elimination of poverty as an obstacle for economic development and political participation, (3) the reorganization of civil-military and state-religion relations, and (4) the re-organization of laws and regulations about the political parties and the election system.

All the respondents, in spite of their different backgrounds and the different ideologies they endorsed, had a consensus of opinion on these issues with the desire for further democratization and joining the EU. However, this consensus on the political matters related with the public sphere seemed to break down when it came to the issues about the private sphere, gender and sexuality.

\section{Gender equity}

In-depth interviews gave an opportunity to the respondents to express their stance in their own ways, and most of the time their responses to the gender equity and sexuality questions were full of hesitation. Their initial reaction was more positive, which later came along with an opposing argument attached with 'but's. This change of opinion in the interviews may be attributed to the social desirability effect of the respondents. The indepth interviews gave us an opportunity to overcome this first positive stand and allowed us to probe more.

The respondents did not oppose women's political participation. Furthermore, all admitted that women were underrepresented in politics. 'Women are underrepresented 
in politics... As the weak part of the society, they should be represented in the politics. Turbey needs this. The quota should not be under 40\%' (Istanbul, Female, Feminist). However, when they were asked about the social barriers and the positive discrimination possibilities, the majority of the respondents were not in favor of taking measures, such as quotas, to deal with social barriers. They revealed their reservations clearly by using such statements as

'Well, I think it (quota) is necessary for a while... indeed it is a nice thought, but if it would not happen in any other way, we would have to...' (Istanbul, Male, Liberal)

'I am sorry to admit that I don't think we will get serious results out of the quota for women...maybe women politicians will act in a sensitive manner towards women? I don't know... the real thing is the level of consciousness about the human rights, politics and democratic values.' (Ankara, Male, Human Right Activist)

'I am in favour of quota but I don't want that women cease to develop themselves because of the quota. I think women should first analyse and then think in depth what is the meaning of being women, what are the problems of women etc.' (Diyarbakar, Female, Activist)

Bringing up such concerns, they argued that it is more convenient to wait for a natural demand from women rather than imposing such measures as quota.

'Very wrong!! I don't take social engineering projects very positively... If a woman or a man is politically engaged, he or she will get into politics. This is a sociological process. You are saying that you want a catalyst to this process, I don't take it as being very healthy, it is like producing hormone induced fruits.' (Diyarbakır, Male, Conservative)

'Absolutely wrong! It has to be left out to its natural course. Women should compete with men. There shouldn't be any barrier in front of her, but positive discrimination is wrong. It causes injustice and it is a waste of energy. I think women shouldn't demand such a thing, they should work and compete with men as their equals.' (Istanbul, Male, Conservative)

'For me, quota has always been something that is not natural. It is something artificial. If something does not occur naturally, we persist on it to occur' (Istanbul, Female, Conservative)

\section{Domestic violence}

It took sometime for the Turkish public to acknowledge domestic violence as a social issue. It is only recently, with the adaptation process to EU, that the political elite had to acknowledge this problem and implement some measures to enforce local governments to initiate shelters for battered women.

'This (domestic violence) is a social problem, open sore... this is definitely related with the development level of a society and also education... in the end, we are an oriental society... it won't go away easily.' (Ankara, Male, Conservative)

The respondents' attitudes towards the involvement of public institutions in interference with domestic violence were not positive. When asked if they agree to the role played by women's shelters when women are subjected to violence, they again came up with conditional acceptance.

'They are very useful but I think that we shouldn't go beyond the purpose... I mean, there will be fights between husband and wife; it is very popular in Turkey that when women get mad, they go to their mothers' house. When there is no mother to go to, they may go to places like these shelters... But this should not go as far as excluding men and the sacredness of the family, that will end in a dangerous point that is against tradition.' (Istanbul, Male, Islamist)

Usually the responses started with a sentence such as 'when there is violence, the state should get involved, but...'. Such responses usually continued with statements that put the sacredness and the unity of the family to the human rights of women. They perceived women as a member of the family rather than as an individual, and stressed to preserve, secure, and control the women within the family. It was not surprising that an unconditional support for women's shelters only came from gays and feminists.

\section{Gay and lesbian rights}

The argument of 'it is the nature of women' argument came to surface once again when we asked our respondents about the public rights of those people who have different sexual orientations other than the heterosexual ones. They all accepted that the differences should be represented, but the 'unnatural' nature of 
homosexual orientations was a common argument among the respondents.

'When I consider the issue as a doctor, I take them (gays and lesbians) normal. But we have to be careful not to encourage such things.' (Diyarbakır, Male, Social Democrat)

While those who came from conservative or religious backgrounds defined homosexuality as a 'deviation', 'abnormality', or 'a modern degeneration', those with more liberal political stance used medical terminology and evaluated homosexuality as some kind of illness to be cured. Most respondents also emphasized how different sexual orientations can be detrimental to the most important social institution: the family. Not only a woman's role but also that of a man in the family was central when opposing homosexuality. Man as the husband and father of the family could not be gay, which would be the destruction of the family - the very foundation of the society and could not be accepted by most of our respondents.

'I am not against gays and lesbians... to tell you the truth, it does not bother me. But when it comes to them having children, of course you need to consider the child.. You will be limiting the child's life and social perception and this will have a negative impact on the psychology of the child.' (Istanbul, Female, Liberal)

'I think that people should not be punished because of their sexual preferences or identities or their private life. (...) However, I find the right of getting married and having children problematic.' (Istanbul, Female, Socialist Muslim)

'I think it (civil rights) should be given to them. But it is important to have these rights with consensus as much as possible.' (Istanbul, Male, Liberal)

\section{Conclusion}

This article agrees with Norris and Inglehart's (2002, p. 261) conclusion that ' $[t]$ he most basic cultural fault line... involves issues of gender equality and sexual liberalization,' and '... these issues have important implications for democracy'. However, when it comes to the analysis of gender equity it is hazardous to make overgeneralizations where one falls into culturalist-essentialist fault line easily. Moghadam (1994, p. 7) warns us that 'culture masks more than it reveals'. Therefore, when we are looking at gender equity and sexual liberty issues in the non-western world, we need to use more dynamic concepts than the essentialist religious perception as has been argued in Norris and Inglehart. Moghadam argues that gender and sexuality are the key pillars of the nonwestern cultures, which almost all the time organize in response to the hegemony of the West. Women as the representative of the nation - culture, produce and reproduce the culture therefore; their bodies are controlled with all the possible means within the family.

'One answer to identity politics which seeks to control women is to disarticulate women from culture, deconstruct women as symbol, reconstruct women as human beings, and problematize women's rights as human rights.' (Moghadam, 1994, 22)

Most of the respondents of this research regardless of their political stance - conservative, liberal, social democrat or Islamist, all had conservative values regarding the enhancement of women's political participation, their sexual liberties, positive discrimination and public involvement with the private sphere, and gay and lesbian rights. This may be attributed to the defensive nature of the identity politics in the Turkey of the 2000s, and that all these political stances have to cope with the contemporary macro political atmosphere in order to preserve their existence. Therefore, although it is possible to understand this convergence of the majority of the political elite towards conservative gender politics and sexual politics, it is also worth to note that only the feminists and the gay and lesbian groups, both of which are marginal in Turkey today, had the challenge to stay out of this discourse.

\section{Endnotes}

${ }^{1}$ A sect of Islam that reveres Ali, the fourth Caliph and Mohammed's son-in-law.

${ }^{2}$ See Weber/Schroeder (1998) for a detailed review of Weber's account on culture, development and democracy.

\section{References}

Almond, Gabriel, \& Verba, Sidney (1963). Culture: political attitudes \& democracy in five nations. Princeton: Princeton Univ. Press.

Arat, Yeșim (1998). Modernleșme Projesi ve Türkiye'de Kadın. In Sibel Bozdoğan, \& Reșat Kasaba (Eds.), Türkiye'de Modernleşme ve Ulusal Kimlik (pp. 82-98). İstanbul: Tarih Vakfi Yurt Yayınları.

Bora, Aksu, \& Ustun, Ilknur (2005). Algılar ve Zihniyet Yapıları: Cinsiyet Rejimi Ekseni. Research Report Istanbul: TESEV.

Cizre, Ümit (2003). Demythologyzing the national security concept: The case of Turkey. Middle East Journal, 57(2), 213-229.

Çakır, Serpil (1996). Türkiye'de Feminizmin Dünü ve BugünüYüzyıl Biterken Cumhuriyet Dönemi Türkiye Ansiklopedisi, Vol. 13. (pp. 750-756) Istanbul: Iletișim Yayınları. 
Cassell, Catherine, \& Johnson, Phil (2006). Action research: Explaining the diversity. Human Relations, 59, 783.

Durakbașa, Ayșe (1998). Kemalism as identity politics in Turkey. In Zehra Arat (Ed.), Deconstructing images of the Turkish woman (pp. 139-155). New York: St. Martin's Press.

Elsadda, Hoda (2004). Women in the Arab world: Reading against the grain of culturalism. Internationale Politik und Gesellschaft/ Jahresregister (pp. 41-53).

Eşim, Simel, \& Cindoğlu, Dilek (1999, January). Women's organizations in 1990's Turkey: Predicaments and prospects. Middle Eastern Studies, 35(1), 178-188.

Heper, Metin (2005). The European Union, the Turkish military and democracy. South European Society and Politics, 10/1, 33-44.

Huntington, Samuel P. (1993). The clash of civilizations, foreign affairs. Summer, 22-49.

Kadığlu, Ayșe (1996). The Paradox of Turkish nationalism and the construction of official identity. Middle Eastern Studies, 32, 177-194.

Kandiyoti, Deniz (1987). Emancipated but Unliberated? Reflections on the Turkish case. Feminist Studies, 13(2), 317-338.

Kırkpınar, Leyla (2001). Türkiye'de Toplumsal Değişme ve Kadın. Ankara: Kültür Bakanlığı Yayınları.

Moghadam, Valentine (1994). Gender and national identity: Women and politics in Muslim societies. In Valentine Moghadam (Ed.), Identity politics and women (pp. 3-26). London: Zed Books.
Norris, Pippa \& Inglehart, Ronald (2002). Islamic culture and democracy: Testing the 'Clash of Civilizations' thesis. Comparative Sociology, 3-4, 235-63.

Norris, Pippa, \& Inglehart, Ronald (2003, March-April). The true clash of civilizations. Foreign Policy, 63-70.

Özbudun, Ergun (2000). Contemporary Turkish politics: challenges to democratic consolidation. Boulder: Lynne Riener Press.

Phillips, Anne (1991). Engendering democracy. University Park, PA: Penn State University.

Putnam, Robert D. (1993). Making democracy work: civic traditions in modern Italy. Princeton: Princeton University Press.

Reason, Peter (2006). Choice and quality in action research practice. Journal of Management Inquiry, 15/2, 187-203.

Tekeli, Șirin (1998). In Ayse Berktay Hacımirzaoğlu (Ed.), Birinci ve Ikinci Dalga Feminist Hareketlerin Karşılaştırmalı Incelemesi Uzerine Bir DenemeYlda Kadınlar ve Erkekler, Vol. 75. (pp. 337-346) Istanbul: Tarih Vakfı Yayınları.

Weber, Max (1998). Democracy and modernization. Edited by Ralph Schroeder. New York: St. Martin's Press. Houdmills, UK: Macmillan.

Yılmaz, Hakan (2006). Türkiye'de Muhafazakarlık, Aile, Din ve Bati: Ilk Sonuclar Uzerine Genel Degerlendirme. Unpublished Research Report (Funded by Open Society Institute and Boğaziçi University). 